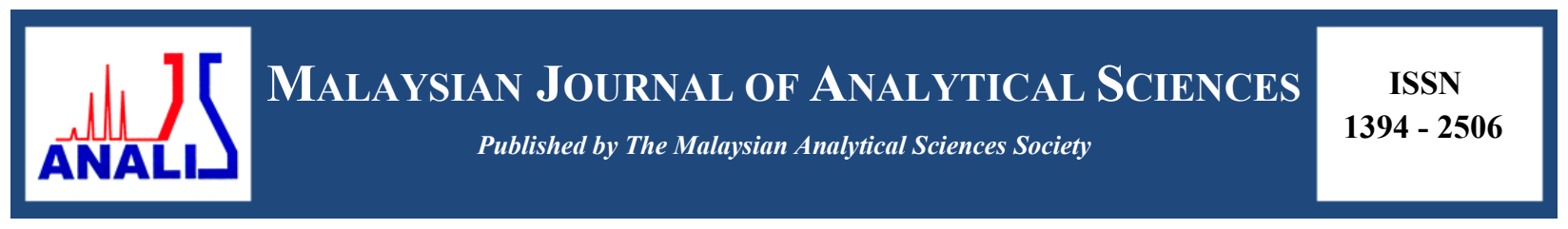

\title{
GROWTH EVALUATION OF MICROALGAE ISOLATED FROM PALM OIL MILL EFFLUENT IN SYNTHETIC MEDIA
}

\section{(Penilaian Pertumbuhan Mikroalga Yang Telah Dipencil Dari Effluen Kilang Minyak Sawit Dalam Media Sintetik)}

\author{
Sharifah Najiha Badar $^{1}$, Zahira Yaakob ${ }^{1}$, Sharifah Najiha Timmiati ${ }^{2}$ \\ ${ }^{1}$ Department of Chemical and Process Engineering, Faculty of Engineering and Built Environment \\ ${ }^{2}$ Fuel Cell Institute \\ Universiti Kebangsaan Malaysia, 43600 UKM Bangi, Selangor, Malaysia \\ *Corresponding author: najihabadar@gmail.com
}

Received: 1 June 2016; Accepted: 8 December 2016

\begin{abstract}
Discharging waste without removing harmful compounds can lead to serious environmental and health issues. Despite of the high content of pollutants, wastewater environment can become an ideal condition for the growth of several microorganisms. Some species of microalgae have been found living in palm oil mill effluent (POME), making it suitable to be used in biological treatment. However, the ability of microalgae to grow and its composition characteristics in synthetic media are unknown. Therefore, this study evaluated the growth characteristics and biochemical productivity of Chlorella sorokiniana UKM3, Coelastrella sp. UKM4 and Chlorella sp. UMACC324, which had been previously isolated from POME. Bold's Basal Media $(\mathrm{BBM})$ was used as the medium for cultivation. The experimental works were performed in a lab-scale photobioreactor at room temperature under continuous illumination for 14 days. From this study, Coelastrella $s p$. UKM4 showed the highest value of growth rates $\left(0.52 \pm 0.03 \mathrm{~d}^{-1}\right)$, biomass productivity $\left(0.07 \pm 0.02 \mathrm{~g} . \mathrm{L}^{-1} \cdot \mathrm{d}^{-1}\right)$, lipid content $\left(66.42 \pm 2.87 \mathrm{mg} . \mathrm{L}^{-1}, 7.26 \%\right)$ and lipid productivity $\left(452.42 \mathrm{mg} \cdot \mathrm{L}^{-1} \cdot \mathrm{d}^{-1}\right)$, whereas the highest chlorophyll content was observed in Chlorella sorokiniana UKM3 $\left(26.84 \pm 1.76 \mathrm{mg} . \mathrm{L}^{-1}\right)$.
\end{abstract}

Keywords: microalgae, growth, biomass, chlorophyll content, lipid content

\begin{abstract}
Abstrak
Pembuangan sisa yang tidak dirawat terlebih dahulu boleh menyebabkan isu yang serius terhadap alam sekitar dan kesihatan. Walaupun kandungan bahan pencemar adalah tinggi, air sisa boleh menjadi habitat yang ideal bagi pertumbuhan sesetengah spesis mikroorganisma. Beberapa spesies mikroalga telah dijumpai hidup dalam effluen kilang minyak sawit (POME). Ini menjadikan spesis mikroalga tersebut sesuai digunakan dalam proses rawatan sisa secara biologikal. Walau bagaimanapun, keupayaan mikroalga untuk bertumbuh dan ciri-ciri komposisinya didalam media sintetik adalah tidak diketahui. Oleh itu, kajian ini dijalankan untuk menilai ciri-ciri pertumbuhan dan produktiviti biokimia bagi Chlorella sorokiniana UKM3, Coelastrella sp. UKM4 dan Chlorella sp. UMACC324, yang sebelum ini telah dipencil dari POME. Media Bold's Basal (BBM) telah digunakan sebagai medium pertumbuhan. Kajian ini telah dilakukan dalam fotobioreaktor berskala-makmal pada suhu bilik dan dibawah pencahayaan yang berterusan selama 14 hari. Daripada hasil kajian ini, Coelastrella sp. UKM4 telah menunjukkan nilai yang tertinggi dalam kadar pertumbuhan $\left(0.52 \pm 0.03\right.$ hari $\left.^{-1}\right)$, produktiviti biojisim $\left(0.07 \pm 0.02{\mathrm{~g} . \mathrm{L}^{-1} \text { hari }}^{-1}\right)$, kandungan lipid $(66.42 \pm 2.87$ mg. $\left.\mathrm{L}^{-1}, 7.26 \%\right)$ dan produktiviti lipid $\left(452.42 \mathrm{mg} . \mathrm{L}^{-1}\right.$.hari $\left.{ }^{-1}\right)$. Kandungan klorofil yang paling tinggi pula dapat dilihat pada Chlorella sorokiniana UKM3 $\left(26.84 \pm 1.76 \mathrm{mg} \cdot \mathrm{L}^{-1}\right)$.
\end{abstract}

Kata kunci: mikroalga, pertumbuhan, biojisim, kandungan klorofil, kandungan lipid 


\section{Introduction}

Algae represent diverse groups of photosynthetic organisms with various sizes and shapes. There are two major types of algae, (a) Microalgae: unicellular and microscopic form of algae with the size of 3-10 $\mu \mathrm{m}$, and (b) macroalgae (giant kelps or seaweeds): multicellular organisms and the most complex form of algae with the size reaching up to $70 \mathrm{~m}$ long [1,2]. These primitive chlorophyll-containing organisms are unique and can be found in various habitats on earth where light is available with little moisture, even in unusual and extreme conditions. Interestingly, algae have different ecological roles, where some algae are attached to other aquatic plants or submerged rocks, while others are found floating in the water. All aquatic animals are dependent directly or indirectly on algae since algae act as the base of the food chain, converting several nutrients into organic matter and oxygenating the water. For instance, aquatic life such as fishes depends on the number of algae. There would be no fish if there are no algae in the lake. Furthermore, the growth of algae is heavily influenced by a number of environmental factors, such as the amount of light penetrating the water, nutrients concentrations, temperature, parasitic relationships (bacteria or fungi), and also salinity of the medium growth [3-7].

On top of that, algae are able to manufacture their own food through photosynthesis like any other terrestrial plants. However, algae lack complex tissues and organs, such as stems and roots, which characterise the complex green plants [8]. These simple structures give them the ability to grow rapidly, doubling their growth within a short period of time. Other than that, algae are efficient in capturing solar energy and utilising carbon dioxide $\left(\mathrm{CO}_{2}\right)$ from their surrounding compared to trees and other green plants $[1,9,10] . \mathrm{CO}_{2}$ plays an important role in microalgae cellular activities. In fact, approximately $50 \%$ of carbon is present in microalgae biomass and this carbon is obtained from the utilisation of $\mathrm{CO}_{2}$ [8]. Furthermore, important biochemical, such as polyunsaturated fatty acids, pigments, lipids, proteins, carbohydrates, and vitamins, can be extracted from algae to be used in the production of high-value products such as fertilisers, cosmetics, and drugs [11-15]. Moreover, several different systems are available to grow algae in industrial sectors, namely open ponds, covered ponds, raceways, and engineered systems (photobioreactors) $[13,16]$. The comparisons of open and closed systems $[17,18]$ are shown in Table 1.

Table 1. Comparisons of open and closed systems

\begin{tabular}{lll}
\hline & Open Systems & Closed Systems \\
\hline Contamination & High risk & Low risk \\
$\mathrm{CO}_{2}$ & High $\mathrm{CO}_{2}$ losses & Lower $\mathrm{CO}_{2}$ losses \\
Evaporation & High evaporation losses & Low evaporation losses \\
Light & Poor light penetration & Excellent light used \\
Scale up & Easy to scale up & Difficult to scale up \\
Process & Difficult to control the process & Easy to control the process \\
Biomass & Low biomass productivity & High biomass productivity \\
Area & Required large area & Low area requirement \\
Harvesting & High cost & Relatively low cost \\
Investment & Low cost & High cost \\
Operation & Low cost & High cost \\
\hline
\end{tabular}

As the world energy demand still depends heavily on fossil fuels, the global oil reserves would eventually become exhausted. The escalating price of oil also has caused dilemma among industrial activities, transportation sectors, and residential needs [19]. Furthermore, the search for suitable biomass from available food crops for biofuel production has indeed generated a lot of controversies. The use of agricultural land solely for biofuels production causes limited land available for food production. Thus, food supply becomes limited and eventually sparks hunger issues, food arguments, and sustainability issues. However, the ability of algae to have high productivities, grow 
easily in the brackish or marine environment, does not need agricultural land and does not compete with edible oil crops makes it suitable to be the new source of biofuels. The land quality and soil fertility is not an issue in cultivating algae because algae grow in water, not soil [20]. Microalgae lipid in the form of triacylglycerides (TAGs) can be transformed into biofuel products, such as methyl ester, biodiesel, and gasoline substitute. Seaweeds biomass also has been considered as a new source of biofuels in the form of biomethane and bioethanol [21,22].

The release of untreated wastewater into the water bodies and high concentration of greenhouse gases in the atmosphere have caused climate change, threatened the global environment, and sparked health issues. Various methods (physical, chemical and biological) have been applied and compared to treat the wastes produced. Previous studies have asserted that the most effective and environmental friendly method is by using the biological approach. Biological treatments rely on microorganisms, such as bacteria, to break down organic wastes by using cellular processes. Apart from using bacteria, microalgae are one of the options to be used in biological treatment. The use of microalgae for the removal of pollutants and $\mathrm{CO}_{2}$ in the wastewater is known as phycoremediation [23-25].

In Malaysia, the increasing demand for palm oil has directly increased the amount of palm oil wastes, such as empty fruit bunches (EFB), palm oil mill effluent (POME), and fibres. POME is a viscous and acidic brown liquid that releases highly unpleasant odour. It is the most expensive and difficult waste to manage compared to the rest. Typically, POME contains high concentration of total solids, organic and inorganic matters, oil, and also heavy metals. The high amount of organic matter causes high level of chemical oxygen demand (COD) and biochemical oxygen demand (BOD). However, some species of microalgae have been found living in the POME environment despite of the high content of pollutants. These microalgae use the organic matter in POME as nutrient for growth. The ability of microalgae to adapt and assimilate nutrient, as well as grow successfully in POME have made them suitable to be used in wastewater treatment. According to Ding et al. [25], POME-isolated microalgae, namely Chlamydomonas sp. UKM6 was able to reduce $29.1 \%$ of COD, $73 \%$ of total nitrogen content, and $63.5 \%$ of total phosphorus content in wastewater. Meanwhile, Tamil Selvam et al. [26] reported that Characium $s p$. isolated from POME was able to reduce $88.6 \%$ of total nitrogen content and $98 \%$ of phosphorus content in anaerobic POME. Besides functioning as nutrient removal, the biomass produced from microalgae in wastewater treatment can be used to produce multiple useable products [27-30].

Although these microalgae are able to thrive in POME, the adaptation ability of each microalga is varied from one species to another. Different environment or growth conditions can affect the ability of microalgae to grow and produce biomass. Thus, the main focus of this research is to determine the capability of POME-isolated microalgae to grow in synthetic media, as well as to compare their potential in producing biomass and biochemical products.

\section{Algae strain}

\section{Materials and Methods}

Three species of microalgae, namely Chlorella sorokiniana UKM3, Coelastrella sp. UKM4, and Chlorella $s p$. UMACC 324 were obtained from Algae Culture Room, Faculty of Engineering and Built Environment, University Kebangsaan Malaysia (UKM), Bangi, Selangor, Malaysia. All the species were previously isolated from palm oil mill effluent.

\section{Preparation of media}

Bold's Basal Media (BBM) is a freshwater algae medium that has been used to grow a variety of algal cultures. It was prepared by adding and mixing ten different components. BBM stock solutions (per litre) contain $25 \mathrm{~g}$ sodium nitrate $\left(\mathrm{NaNO}_{3}\right) ; 2.5 \mathrm{~g}$ calcium chloride dehydrate, $\left(\mathrm{CaCl}_{2} .2 \mathrm{H}_{2} \mathrm{O}\right) ; 7.5 \mathrm{~g}$ magnesium sulfate heptahydrate $\left(\mathrm{MgSO}_{4} .7 \mathrm{H}_{2} \mathrm{O}\right) ; 7.5 \mathrm{~g}$ potassium phosphate $\left(\mathrm{K}_{2} \mathrm{HPO}_{4}\right) ; 17.5 \mathrm{~g}$ monopotassium phosphate $\left(\mathrm{KH}_{2} \mathrm{PO}_{4}\right) ; 2.5 \mathrm{~g}$ sodium chloride $(\mathrm{NaCl}) ; 11.42 \mathrm{~g}$ boric acid $\left(\mathrm{H}_{3} \mathrm{BO}_{3}\right)$; Alkaline EDTA solution containing 50 g ethylenediaminetetraacetic acid (EDTA); and $31 \mathrm{~g}$ potassium hydroxide $(\mathrm{KOH})$; Acidified iron solution containing $4.98 \mathrm{~g}$ iron (II) sulfate heptahydrate $\left(\mathrm{FeSO}_{4} \cdot 7 \mathrm{H}_{2} \mathrm{O}\right)$; and $1 \mathrm{ml}$ concentrated sulfuric acid $\left(\mathrm{H}_{2} \mathrm{SO}_{4}\right)$; Trace Metal solution containing $8.82 \mathrm{~g}$ zinc sulfate heptahydrate $\left(\mathrm{ZnSO}_{4} .7 \mathrm{H}_{2} \mathrm{O}\right) ; 1.44 \mathrm{~g}$ manganese (II) chloride tetrahydrate $\left(\mathrm{MnCl}_{2} .4 \mathrm{H}_{2} \mathrm{O}\right) ; 0.71 \mathrm{~g}$ molybdenum trioxide $\left(\mathrm{MoO}_{3}\right) ; 1.57 \mathrm{~g}$ copper (II) sulfate pentahydrate $\left(\mathrm{CuSO}_{4} .5 \mathrm{H}_{2} \mathrm{O}\right)$; and $0.49 \mathrm{~g}$ cobalt (II) Nitrate Hexahydrate $\left(\mathrm{Co}\left(\mathrm{NO}_{3}\right)_{2} \cdot 6 \mathrm{H}_{2} \mathrm{O}\right)[31,32]$. 


\section{Preparation of inoculums}

The POME-isolated microalgae stock cultures $(10 \% \mathrm{v} / \mathrm{v})$ were grown in Erlenmeyer flask $(250 \mathrm{ml})$ containing 100 $\mathrm{ml}$ of synthetic media. Erlenmeyer flask opening was closed with sterile non-absorbance cotton wool. The culture was then incubated at constant room temperature $\left(25 \pm 1{ }^{\circ} \mathrm{C}\right)$, shaken at $100 \mathrm{rpm}$ using an orbital shaker with 24 hours illuminations. After 10 days, the cultures were ready to be used as inoculums when the OD reading reached 1.0 at a wavelength of $750 \mathrm{~nm}$. Sub-culturing the microalgae culture has to be done every month in order to ensure the viability of the culture.

\section{Experimental procedure}

The experimental vessels were made by converting 1 litre Erlenmeyer flasks into lab-scale photobioreactors. Microalgae cultures were sparged with ambient air that was supplied by the gas compressor. The opening flasks were closed using silicone stopper. The air was introduced into all the flasks through sterilised silicon tube at 0.5 vvm (gas volume flow per unit of liquid volume per minute), constantly. Cool white fluorescent lamps were uniformly aligned behind the photobioreactors. These artificial lights were continuously supplied at an intensity of $54 \mu \mathrm{mol} \mathrm{m} \mathrm{m}^{-2} \mathrm{~s}^{-1}$. All sets of experiments were undertaken at room temperature $\left(25 \pm 1{ }^{\circ} \mathrm{C}\right)$ in batch mode and each experimental condition was conducted in duplicate. The $\mathrm{pH}$ of growth medium was not maintained throughout the experiment period. The samples were taken every 24 hours for 14 days. Figure 1 illustrates the experimental set up of the three strains of POME-isolated microalgae.

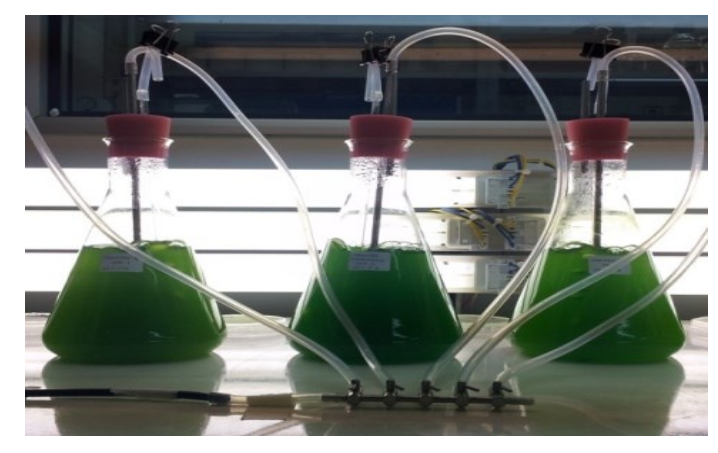

Figure 1. Experimental set-up

\section{Optical density (OD)}

The optical densities of growing cultures were measured by using portable spectrophotometer (HACH DR 2800, USA) at a wavelength of $750 \mathrm{~nm}[33,34]$. The specific growth rate, $\mu\left(\right.$ day $\left.^{-1}\right)$ of microalgae was calculated by using Equation (1) below:

$$
\mu=\frac{\ln x_{2}-\ln x_{1}}{t_{2}-t_{1}}
$$

where, $x_{1}$ and $x_{2}$ represent OD readings at $750 \mathrm{~nm}$, while $t_{1}$ and $t_{2}$ are the time interval $[35,36]$.

The maximum specific growth rate, $\mu_{\max }\left(\mathrm{day}^{-1}\right)$ was determined by using Logistic equation based on the optical density results. The rate of microalgae growth $(d x / d t)$ is shown below $[37,38]$.

$$
\frac{d X}{d t}=\mu_{\max }\left(1-\frac{X}{X_{\max }}\right) X
$$

At the beginning of growth where $t=t_{o}$, the microalgae concentration was given by the initial concentration value $\left(X=X_{o}\right)$. After integration, Equation (2) becomes: 


$$
X=\frac{X_{O} X_{\max } e^{\mu} \max ^{t}}{X_{\max }-X_{o}+X_{o} e^{\mu} \max ^{t}}
$$

where, $X$ is the concentration of microalgae, $X_{o}$ is the initial concentration of microalgae, $X_{\max }$ is the maximum value of the microalgae concentration, and $t$ is the time during cultivation. The calculations were carried out using MATLAB R2013a programme.

\section{Cell dry weight (CDW)}

The microalgae biomass was determined based on cell dry weight method. The microalgae samples were taken and filtered using vacuum filter accompanied with Whatman $\mathrm{GF} / \mathrm{C}$ filter paper $(1.2 \mu \mathrm{m}$ pore sizes). Then, these filter papers were allowed to be dried in the oven (DHG 9146-A, China) overnight at $105^{\circ} \mathrm{C}$ until a constant weight was achieved. The cell weight was measured using an analytical balance (XB 220A, Switzerland) and calculated using Equation (4). Besides, the biomass productivity of microalgae was calculated using Equation (5) below [11].

$$
\begin{aligned}
& \text { Cell dry weight, }\left(\mathrm{g} \cdot \mathrm{L}^{-1}\right)=\frac{X_{f}-X_{o}}{V} \\
& \text { Biomass productivity }\left(\mathrm{g} \cdot \mathrm{L}^{-1} \cdot \mathrm{d}^{-1}\right)=\frac{\Delta X}{\Delta t}=\frac{\left(X_{t}-X_{o}\right)}{\left(t-t_{o}\right)}
\end{aligned}
$$

where, $X_{o}$ is initial weight of filter paper $(\mathrm{g}), X_{f}$ is filter paper weight after filtration $(\mathrm{g}), V$ is the volume of microalga culture (L), while $X_{t}$ and $X_{o}$ are dry weights $\left(\mathrm{g} . \mathrm{L}^{-1}\right)$ at time $t$ and $t_{o}$ respectively.

The efficiency of $\mathrm{CO}_{2}$ fixation was calculated in terms of $\mathrm{CO}_{2}$ consumed by microalgae. The $\mathrm{CO}_{2}$ consumption rate was calculated by using Equation (6). It was derived from the typical molecular formula of microalgae biomass, $\mathrm{CO}_{0.48} \mathrm{H}_{1.83} \mathrm{~N}_{0.11} \mathrm{P}_{0.01}[39,40]$.

$$
\mathrm{CO}_{2} \text { consumption rate, } \mathrm{P}_{\mathrm{CO} 2}\left(\mathrm{~g} \mathrm{CO}_{2} \cdot \mathrm{L}^{-1} \mathrm{~d}^{-1}\right)=1.88 \times \text { biomass productivity }
$$

\section{Chlorophyll content}

The cultures were harvested and centrifuged at $5000 \mathrm{rpm}$ for 10 minutes. The supernatant was discarded. Furthermore, in order to extract the pigments, the collected samples were re-suspended with $90 \%$ methanol until the biomass appeared colourless. The cell debris was then removed via centrifugation. The absorbance of the extracted solvent was measured against a blank solvent at the given wavelengths using a portable spectrophotometer (HACH DR 2800, USA). The chlorophyll content was estimated using the following equations [41].

$$
\begin{aligned}
& \text { Chlorophyll } a\left(\mathrm{mg} \cdot \mathrm{L}^{-1}\right)=\left(16.5 \times A_{665}\right)-\left(8.3 \times A_{650}\right) \\
& \text { Chlorophyll } b\left(\mathrm{mg} \cdot \mathrm{L}^{-1}\right)=\left(33.8 \times A_{650}\right)-\left(12.5 \times A_{665}\right) \\
& \text { Chlorophyll } a+b\left(\mathrm{mg} \cdot \mathrm{L}^{-1}\right)=\left(4.0 \times A_{665}\right)+\left(25.2 \times A_{650}\right)
\end{aligned}
$$

\section{Lipid content}

The cultures were collected via centrifugation at $5000 \mathrm{rpm}$ for 10 minutes. The supernatant was discarded. The lipid in microalgae cells was extracted using Folch method [42]. The collected cells after centrifugation were mixed with chloroform-methanol $(2: 1 \mathrm{v} / \mathrm{v})$ and sonicated. An amount of $0.9 \%$ sodium chloride $(\mathrm{NaCl})$ was added to the mixture and left overnight. Next, the lower phase was collected and allowed to evaporate to remove the organic solvent. Moreover, sulfuric acid was added to the samples and incubated in boiling water for $10 \mathrm{minutes}$. Then, $5 \mathrm{ml}$ of sulfophospho-vanillin [43] was added and the samples were measured at 520nm. The lipid standard curve was established by using cholesterol. The values of lipid content (\%) and productivity were calculated using the equations below [11].

$$
\begin{aligned}
& \text { Lipid content }(\%)=\frac{W_{2}}{W_{1}} \times 100 \% \\
& \text { Lipid productivity, } Y\left(\mathrm{mg} . \mathrm{L}^{-1} \mathrm{day}^{-1}\right)=\frac{L \times \Delta W_{1}}{\Delta t}
\end{aligned}
$$


where, $W_{l}$ is total biomass produced in day $\left(\mathrm{mg} . \mathrm{L}^{-1}\right), W_{2}$ is total lipid content $\left(\mathrm{mg} . \mathrm{L}^{-1}\right), L$ is lipid content $(\%), \Delta t$ is duration of cultivation (day) and $\Delta \mathrm{W}_{1}$ is variation of biomass concentration $\left(\mathrm{mg} . \mathrm{L}^{-1}\right)$.

\section{Microalgae growth evaluation}

\section{Results and Discussion}

Synthetic media are artificial and simplified media that are designed to provide nutrients for growth of freshwater algae, as well as for maintaining algal strains. In microbial cell suspensions, cell turbidity can be determined easily by using the optical density method [44]. However, inaccuracies can occur due to the existence of pigments (chlorophyll $a$ and $b$ ) content. Thus, the suitable wavelength that minimises the pigment absorbance should be carefully selected. For algal suspensions, the error can be minimised by measuring the cell density at a wavelength beyond the range of chlorophyll contents, such as at $750 \mathrm{~nm}$. In this experiment, all three isolated microalgae were cultured in batch mode for 14 days without any optimisation factor that might affect the growth and biochemical composition. The results indicated that each species showed similar trends and adhered to the standard growth curve for microalgae. The algal growth curves based on OD 750nm are shown in Figure 2. All the microalgae underwent lag, exponential, and stationary phases when growing in synthetic media. Based on the graph, the lag phase of all the species was consistent from day 0 to day 4 , followed by exponential phase (day 4 to day 10), and stationary phase (day 10 to day 14). However, the decline (death) phase was not achieved by day 14 . The initial $\mathrm{pH}$ of BBM medium was around 6.9 to 7.1 and this value was observed to increase (up to $\mathrm{pH} \mathrm{8.0)}$ ) as the culture grew. The rise of $\mathrm{pH}$ levels is a good indicator as it shows that the microalgae are indeed growing in the culture medium. According to Borowitzka [45] and Goldman et al. [46], the pH value usually increases due to the photosynthetic activity of microalgae.

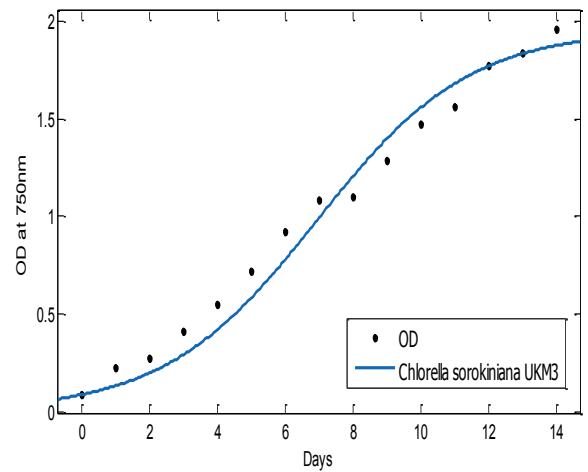

(a) Chlorella sorokiniana UKM3

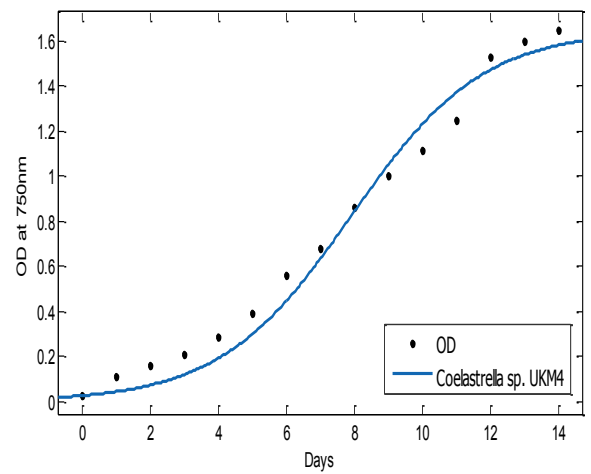

(b) Coelastrella sp. UKM4

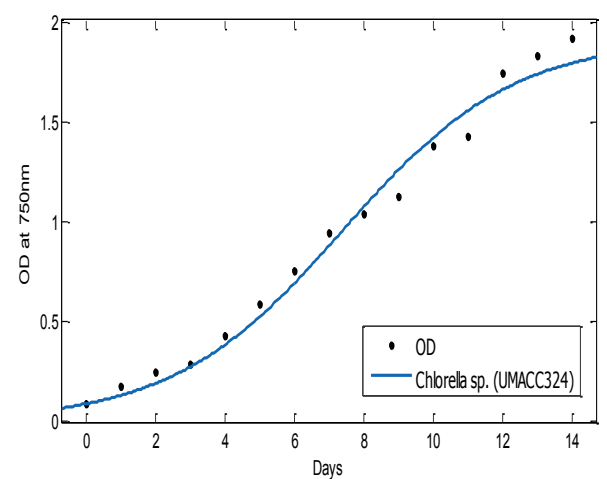

(c) Chlorella sp. UMACC324

Figure 2. Growth curves of POME-isolated microalgae at $\mathrm{OD}_{750 \mathrm{~nm}}$ 
According to Dailey and Reish [47], some algae species grow by increasing their cell number (cell division), rather than in size. The rate of cell division was varied according to the species and their living conditions. The increasing of algal biomass over a period of time is known as the new production or growth rate. Specific growth rate refers to the cell regeneration, which is the way of how fast the cells are dividing in a culture. Most of microalgae growth process can be explained by using the Logistic model. It is a common model of population growth with sigmoid profiles independent of substrate concentration [37]. The growth rates of each microalga species were calculated based on Equations (1) and (3). The results for growth rates are shown in Table 2.

Table 2. Growth rates of POME-isolated microalgae in synthetic media

\begin{tabular}{lccc}
\hline Microalgae sp. & $\begin{array}{c}\text { Specific Growth } \\
\text { Rate, } \boldsymbol{\mu}\left(\mathbf{d}^{-1}\right)\end{array}$ & $\begin{array}{c}\text { Maximum Specific } \\
\text { Growth Rate, } \boldsymbol{\mu}_{\max } \\
\left(\mathbf{d}^{-1} \mathbf{)}\right.\end{array}$ & Logistic Equation \\
\hline $\begin{array}{l}\text { Chlorella sorokiniana } \\
\text { UKM3 }\end{array}$ & $0.20 \pm 0.05$ & $0.44 \pm 0.02$ & $X=\frac{0.17 e^{0.44 t}}{1.87+0.09 e^{0.44 t}}$ \\
Coelastrella sp. UKM4 & $0.22 \pm 0.03$ & $0.52 \pm 0.03$ & $X=\frac{0.05 e^{0.52 t}}{1.62+0.03 e^{0.52 t}}$ \\
$\begin{array}{l}\text { Chlorella sp. } \\
\text { UMACC324 }\end{array}$ & $0.19 \pm 0.04$ & $0.41 \pm 0.01$ & $X=\frac{0.18 e^{0.41 t}}{1.83+0.09 e^{0.41 t}}$ \\
\hline
\end{tabular}

The growth rate of microalgae can be altered by optimising and modifying the growth conditions. Besides that, the increase of inoculum density also can affect the algal growth. A study conducted by Griffith and Harrison et al. [48] stated that the growth rate, $\mu$, decreased when the concentrations of inoculum increased. Thus, in this study, only one inoculum density at OD reading of 1.0 was used in all runs. Based on the results shown in Table 2, Coelastrella $s p$. UKM4 achieved the highest growth rate, followed by Chlorella sorokiniana UKM3 and Chlorella $s p$. UMACC324. In addition, Tamil Selvam [49] discovered that the specific growth rate for Chlorella sorokiniana in BBM medium was $0.18 \pm 0.01 \mathrm{~d}^{-1}$. This value is slightly lower than the result obtained in this study, whereby $\mu$ attained by Chlorella sorokiniana UKM3 was $0.20 \pm 0.05 \mathrm{~d}^{-1}$. Meanwhile, according to Vello et al. [50], the specific growth rates for Chlorella sp. UMACC322 and UMACC 325 were $0.49 \pm 0.02 \mathrm{~d}^{-1}$ and $0.51 \pm 0.1 \mathrm{~d}^{-1}$, respectively. The values are higher compared to the growth rate displayed by the Chlorella strain in this study. The variation of algal growth rates usually related to the growth conditions and algal requirements [5-7].

Moreover, primary productivity was obtained by measuring the increase in biomass over a period of time. Productivity or called yield in mass algal culture differs from standing crop biomass. A standing crop can be described as the total dried biomass of the living organisms present in a given environment. The total biomass of standing crop may be high, but the productivity would be low. Occasionally, low biomass content shows high productivity and specific growth rates, or possibly the other way around. Maximum yield or productivity is usually obtained at intermediate densities and growth rates, while maximum growth rates usually occur at lower density. High densities cause slower growth rates due to several limiting factors, which alter the biochemical aspect within the cells. Besides, algal biomass would continue to increase until a factor limits its generation [51]. The shadowing effect also can cause a decrease in specific growth rates but higher biomass concentrations can be achieved. Furthermore, in a condition where light or nutrients are limited, low biomass concentration and high specific growth rates are expected to occur in the cultivation systems [52-54].

In this experiment, Coelastrella strain attained higher biomass productivity $\left(0.07 \pm 0.02 \mathrm{~g} \cdot \mathrm{L}^{-1} \cdot \mathrm{d}^{-1}\right)$ in comparison to Chlorella sorokiniana and Chlorella sp. The productivity results are comparable with the microalgae growth rate. The higher productivity and growth rate achieved by Coelastrella sp. UKM4 showed that this microalga has the potential to be cultivated in a large-scale production to generate biomass for fertilisers, animal feed, and other 
products. However, Minhat et al. [55] reported that the biomass concentration of Chlorella sorokiniana UKM3 in BBM was 2.52 g. $\mathrm{L}^{-1}$, which is higher than the result obtained in this study. The results of biomass concentration, productivity, and $\mathrm{CO}_{2}$ consumption rates are presented in Table 3 . The consumption of $\mathrm{CO}_{2}$ is related directly to the biomass production. As the biomass increases, the consumption rate also increases. Therefore, Coelastrella sp. has the potential to be used in carbon sequestration process compared to other strains.

Table 3. Biomass concentration, productivity, and $\mathrm{CO}_{2}$ consumption rates of POME-isolated microalgae

\begin{tabular}{|c|c|c|c|}
\hline Microalgae sp. & $\begin{array}{c}\text { Biomass Concentration } \\
\left(\mathrm{g} . \mathrm{L}^{-1}\right)\end{array}$ & $\begin{array}{c}\text { Biomass Productivity } \\
\left(\mathrm{g} \cdot \mathrm{L}^{-1} \cdot \mathrm{d}^{-1}\right)\end{array}$ & $\begin{array}{c}\mathrm{CO}_{2} \text { Consumption Rate } \\
\left(\mathrm{g} \mathrm{CO}_{2} \cdot \mathrm{L}^{-1} \mathrm{~d}^{-1}\right)\end{array}$ \\
\hline $\begin{array}{l}\text { Chlorella sorokiniana } \\
\text { UKM3 }\end{array}$ & 0.86 & $0.06 \pm 0.02$ & $0.11 \pm 0.03$ \\
\hline $\begin{array}{l}\text { Coelastrella sp. } \\
\text { UKM4 }\end{array}$ & 0.95 & $0.07 \pm 0.02$ & $0.13 \pm 0.04$ \\
\hline $\begin{array}{l}\text { Chlorella sp. } \\
\text { UMACC } 324\end{array}$ & 0.78 & $0.05 \pm 0.01$ & $0.09 \pm 0.01$ \\
\hline
\end{tabular}

\section{Biochemical content evaluation}

Pigmentation and storage product are important criteria in the classification of algae. Different groups of algae exhibit various colours due to the differences found in pigmentation. All the microalgae species used in this study are members of the division Chlorophyta or green algae. The pigments of green algae are chlorophyll $a$ and $b$, whereas their accessory pigments are carotenoids and xanthophylls. Chlorophyll (green pigment) is an extremely important biomolecule for photosynthesis and growth. Furthermore, microalgae with high pigment content have the potential to be used as sources of dyes [6,7]. In this experiment, microalgae were treated using methanol to extract the chlorophyll content. Figure 3 illustrates the amount of chlorophyll content in each species. Based on the graphs, Chlorella sorokiniana UKM3 showed the highest chlorophyll content $(\mathrm{Chl} a+b)$ which is $26.84 \pm 1.76 \mathrm{mg} \cdot \mathrm{L}^{-1}$ at day 13. This value is higher compared to the result obtained by Tamil Selvam [49], which is $12.24 \pm 0.48 \mathrm{mg} . \mathrm{L}^{-1}$. As for Coelastrella sp. UKM4, the chlorophyll content was the highest $\left(26.47 \pm 6.14 \mathrm{mg} . \mathrm{L}^{-1}\right)$ at day 10, while Chlorella sp. UMACC 324 was at day $13\left(26.21 \pm 0.49 \mathrm{mg} . \mathrm{L}^{-1}\right)$. The chlorophyll content for all the species began to increase drastically from day 3 until day 8 before reaching stationary state. After day 11, the chlorophyll content in Coelastrella sp. showed a reduction $\left(19.63 \mathrm{mg} . \mathrm{L}^{-1}\right)$. The reduction of chlorophyll content is directly related to the reduction of photosynthesis activity [56]. Besides, both Chlorella strains showed better performance in terms of chlorophyll availability compared to Coelastrella $s p$. at the end of cultivation. Although the microalgae used in this study are from the same division, the chlorophyll content presented in each species differed slightly. However, the amounts have been comparable with each other.

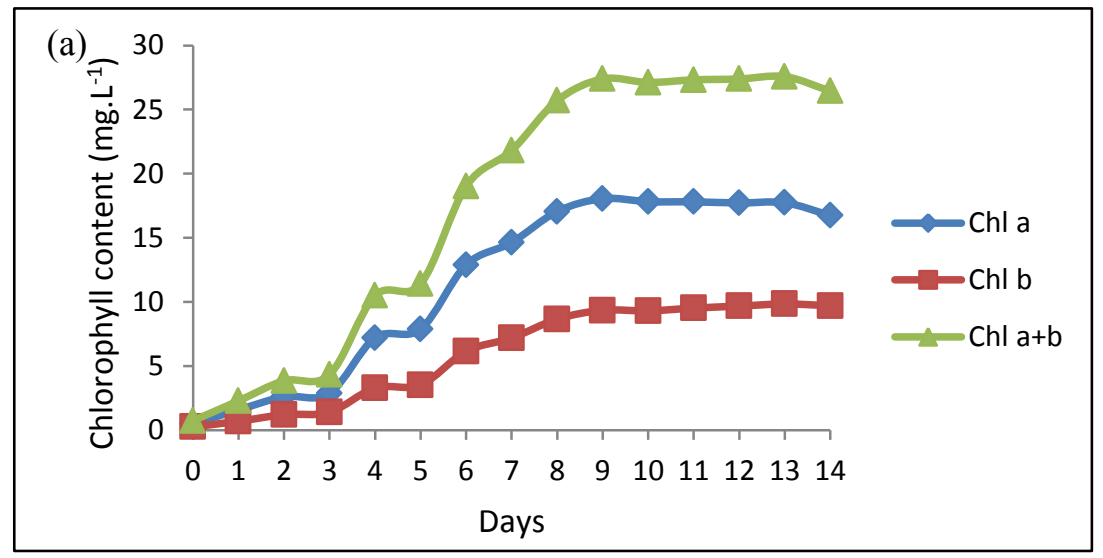



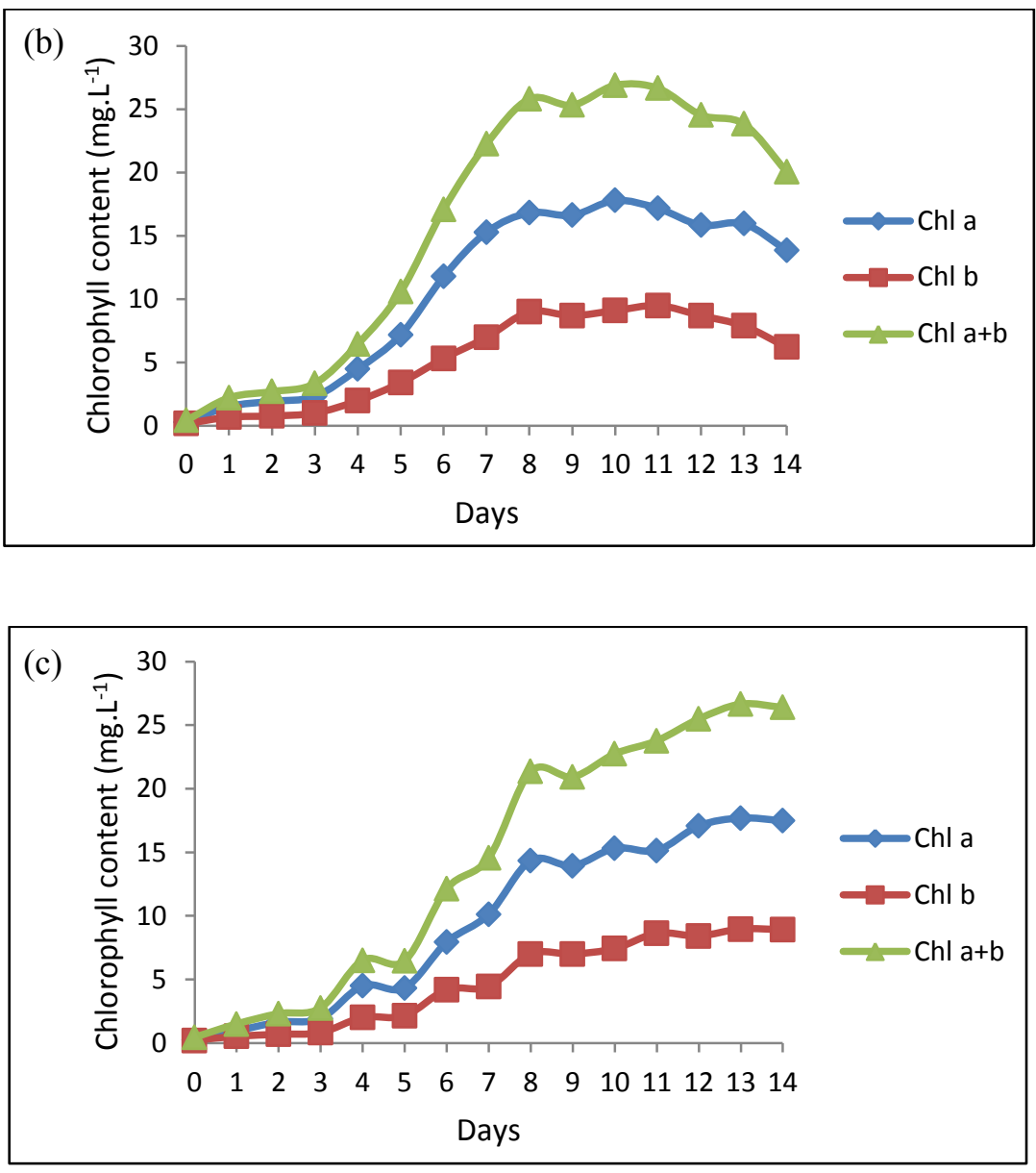

Figure 3. Chlorophyll content in POME-isolated microalgae (a) Chlorella sorokiniana UKM3, (b) Coelastrella sp. UKM4 and (c) Chlorella sp. UMACC324

Algae store their lipids in various ways; depending on the species, growth conditions and also the growth stage when microalgae are harvested. When algal cells are actively growing, the major lipids found within the cells are in the form of glycolipids and phospholipids. The overall lipid profile changes when algae enter a less active growth phase or encounter environmental stress. Algae will slow down their rate of proliferation and start to store Triacylglycerides (TAGs) as the dominant lipid in cell vacuoles [19, 57-59]. In this experiment, microalgae lipids were extracted by employing the Folch method and then estimated using the sulfophospho-vanillin (SPV) method. Furthermore, the lipid content was calculated by using the cholesterol standard curve. Figure 4 shows the lipid content $\left(\mathrm{mg} . \mathrm{L}^{-1}\right)$ for each microalga, while Table 4 presents the percentages of lipid content and lipid productivity. 


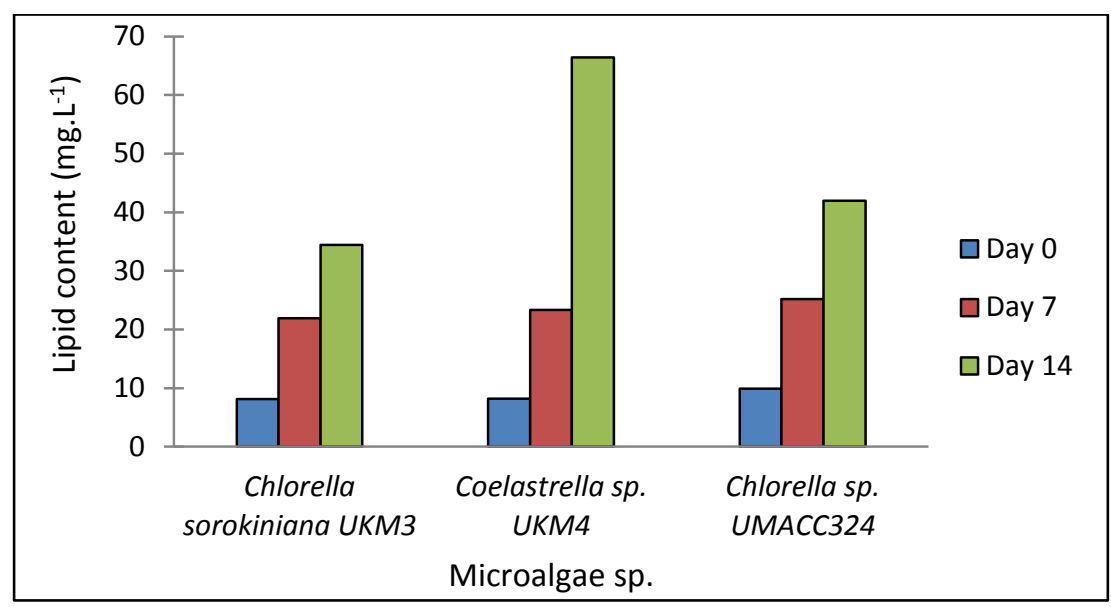

Figure 4. Lipid content $\left(\mathrm{mg} . \mathrm{L}^{-1}\right)$ of POME-isolated microalgae

Table 4. Lipid content (\%) and lipid productivity of microalgae in synthetic media

\begin{tabular}{|c|c|c|}
\hline Microalgae sp. & $\begin{array}{l}\text { Lipid Content } \\
(\%)\end{array}$ & $\begin{array}{l}\text { Lipid Productivity } \\
\left(\mathrm{mg}^{-\mathrm{L}^{-1}} \cdot \mathrm{d}^{-1}\right)\end{array}$ \\
\hline Chlorella sorokiniana UKM3 & 4.65 & 221.03 \\
\hline Coelastrella sp. UKM4 & 7.26 & 452.42 \\
\hline Chlorella sp. UMACC324 & 6.68 & 269.74 \\
\hline
\end{tabular}

Figure 4 depicts that the lipid content of microalgae increased as the culture grew from day 0 (lag phase) to day 14 (stationary phase). At the end of this experiment (day 14), the highest lipid content was recorded in Coelastrella $s p$. UKM4 (66.42 $\left.\pm 2.87 \mathrm{mg} . \mathrm{L}^{-1}\right)$, followed by Chlorella sp. UMACC324 (41.94 $\left.\pm 1.73 \mathrm{mg} . \mathrm{L}^{-1}\right)$ and Chlorella sorokiniana UKM3 (34.43 $\left.\pm 1.38 \mathrm{mg} \cdot \mathrm{L}^{-1}\right)$. Although Chlorella sorokiniana UKM3 produced high biomass concentration compared to Chlorella sp. UMACC324, the values of lipid content and productivity had been the lowest. However, Tamil Selvam [49] reported that Chlorella sorokiniana attained $72.14 \pm 2.01 \mathrm{mg} . \mathrm{L}^{-1}$ of lipid content, which is higher than the result obtained in this study. According to Sarmidi [60], the variation of lipid content in microalgae cultured in batch mode is directly related to the culture age, as well as nutrient depletion.

\section{Conclusion}

This study examined the growth rates and biochemical compositions of POME-isolated microalgae when cultured in synthetic media. Coelastrella sp. UKM4 showed better performance in terms of growth rates, biomass concentration and lipid content. However, Chlorella sorokiniana UKM3 exhibited the highest chlorophyll content compared to other species. The studies pertaining to the microalgae growth are definitely useful and offer important data for cell growth optimisation process, besides understanding their adaptability in different growth conditions. The biochemical products generated by microalgae are also economically useful in various industries for a wide range of purposes. Microalgae species with high growth rate and biochemical content have the potential to be used in the production of biofuels, dyes, and other high valuable products. Therefore, future work is required to fully characterise the microalgae compositions in order to predict its potential for the future development of algae-based industries.

\section{Acknowledgement}

The authors would like to thank and acknowledge Grant KK-2014-014 from Universiti Kebangsaan Malaysia (UKM) in providing the financial support for this project. 


\section{References}

1. Hillison, C. I. (1977). Seaweeds, A color-coded, illustrated guide to common marine plants of east coast of the United States. Keystone Books. The Pennsylvania State University Press: pp. 1 - 5.

2. Garson, J. (1989). Marine natural products. Natural Product Reports, 6: 143 - 170.

3. Hoffmann, L. (1989). Algae of terrestrial habitats. The Botanical Review, 55: 77 - 105.

4. Satpati G. G., Barman, N., Chakraborty, T. and Pal, R. (2011). Unusual habitat of algae. Journal of Algal Biomass Utilization, 2(4): $50-52$.

5. Black, J. G. (2008). Microbiology. Seventh ed. International Student Version. John Wiley \& Sons (Asia) Pte. Ltd.

6. Campbell, N. A. and Reece, J. B. (2005). Biology. Seventh Ed. Pearson Education. San Francisco: Inc. Benjamin Cummings.

7. Talaro, K. P. (2009). Foundations in microbiology. Basic Principle, Sixth Ed. New York: McGraw-Hill: pp. 809.

8. Barsanti, L. and Gualtieri, P. (2006). Algae biotechnology. In: Algae: Anatomy, biochemistry, and biotechnology CRC Press Taylor and Francis Group, Boca Raton: pp. 324 - 359.

9. Cheng, J., Huang, Y., Feng, J., Sun, J., Zhou, J. and Cen, K. (2013). Improving $\mathrm{CO}_{2}$ fixation efficiency by optimizing Chlorella PY-ZUI culture conditions in sequential bioreactors. Bioresource Technology, 144: 321 327.

10. Anjos, M., Fernandes, B. D., Vicente, A. A., Teixeira, J. A. and Dragone, G. (2013). Optimization of CO biomitigation by Chlorella vulgaris. Bioresource Technology, 139: 149-154.

11. Hakalin, N. L. S., Paz, A. P., Aranda, D. A. G. and Moraes, L. M. P. (2014). Enhancement of cell growth and lipid content of a freshwater microalgae Scenedesmus sp. by optimizing nitrogen, phosphorus and vitamin concentrations for biodiesel production. Natural Sciences, 6: $1044-1054$.

12. Pulz, O. and Gross, W. (2004). Valuable products from biotechnology of microalgae. Applied Microbiology and Biotechnology, 65(6): $635-648$.

13. Chisti, Y. (2007). Biodiesel from microalgae. Biotechnology Advances, 25(3): 294 - 306.

14. Spolaore, P., Joannis-Cassan, C., Duran, E. and Isambert, A. (2006). Commercial applications of microalgae. Journal of Bioscience and Bioengineering, 101: 87 - 96.

15. Iriani, D., Suriyaphan, O. and Chaiyanate, N. (2011). Effect of iron concentration on growth, protein content and total phenolic content of Chlorella sp. cultured in basal medium. Sains Malaysiana, 40(4): 353 - 358.

16. Grima, E. M., Fernandez, F. G. A., Camacho, F. G. and Chisti, Y. (1999). Photobioreactors: Light regime, mass transfer and scaleup. Journal of Biotechnology, 70: $231-247$.

17. Pulz, O. (2001). Photobioreactors: Production systems for phototrophic microorganisms. Applied Microbiology and Biotechnology, 57: $287-293$.

18. Grobbelaar, J. U. (2000). Physiological and technological considerations for optimising mass algal cultures. Journal of Applied Physiology, 12: 201 - 206.

19. Oncel, S. S. (2013). Microalgae for macroenergy world. Renewable and Sustainable Energy Reviews, $26: 241$ 264.

20. FAO, Food \& Agriculture Organization of United Nation. (2009). Algae based biofuels: A review of challenges and opportunities for developing countries: pp. $1-60$.

21. Hughes, A. D., Kelly, M. S., Black, K. D. and Stanley, M. S. (2012). Biogas from macroalgae: Is it time to revisit the idea? Biotechnology for Biofuels, 5: $1-7$.

22. Stanley, M. S. and Day, J. G. (2014). Algal bioenergy. In: John Wiley \& Sons, Ltd: Chichester: pp. $1-10$.

23. Sydney, E. B., Strum, W., de Carvalho, J. C., Thomaz-Soccol, V., Larroche, C., Pandey, A. and Soccol, C. R. (2010). Potential carbon dioxide fixation by industrially important microalgae. Bioresource Technology, 101: $5892-5896$.

24. Bilanovic, D., Andargatchew, A., Kroeger, T. and Shelef, G. (2009). Freshwater and marine microalgae sequestering of $\mathrm{CO}_{2}$ at different $\mathrm{C}$ and $\mathrm{N}$ concentrations - response surface methodology analysis. Energy Conversion and Management, 50: $262-267$.

25. Ding, G. T., Yaakob, Z., Takriff, M. S., Salihon, J. and Abd Rahaman, M. S. (2016). Biomass production and nutrient removal by a newly-isolated microalgal strain Chlamydomonas sp. in palm oil mill effluent (POME). International Journal of Hydrogen Energy, 41: 4888 - 4895. 
26. Tamil Selvam, T. B., Renganathan, R. and Takriff, M.S. (2015). Nutrient removal of POME using POME isolated microalgae strain, Characium sp. Advanced Materials Research, 1113: 364 - 369.

27. Basiron, Y. (2007). Palm oil production through sustainable plantations. European Journal of Lipid Science and Technology, 109: $289-295$.

28. Bhatia, S., Othman, Z. and Ahmad, A. L. (2007). Pretreatment of palm oil mill effluent (POME) using Moringa oleifera seeds as natural coagulant. Journal of Hazardous Materials, 145 (1-2): 120 - 126.

29. Putri, E. V., Md. Din, M. F., Ahmed, Z., Jamaluddin, H. and Chelliapan, S. (2011). Investigation of microalgae for high lipid content using palm oil mill effluent (POME) as carbon source. International Conference on Environment and Industrial Innovation, 12: $85-89$.

30. Zainal, A., Yaakob, Z., Takriff, M. S., Rajkumar, R. and Abdul Ghani, J. (2012). Phycoremediation in anaerobically digested palm oil mill effluent using cyanobacterium, Spirulina platensis. Journal of Biobased Materials and Bioenergy, 6: 1- 6.

31. Bold, H. C. (1949). The morphology of Chlamydomonas chlamydogama sp. nov. Bulletin of the Torrey Botanical Club, 76: $101-108$.

32. Bischoff, H. W. and Bold, H. C. (1963). Phycological studies IV. Some soil algae from enchanted rock and related algal species. University of Texas, Austin, 6318: pp. 1 - 95.

33. Griffiths, M. J., Garcin, C., Van Hille, R. P. and Harrison, S. T. (2011). Interference by pigment in the estimation of microalgal biomass concentration by optical density. Journal of Microbiological Methods, 85(2): $119-123$.

34. Lizzul, A. M., Hellier, P., Purton, S., Baganz, F., Lamommatos, N. and Campos, L. (2014). Combined remediation and lipid production using Chlorella Sorokiniana grown on wastewater and exhaust gases. Bioresource Technology, 151: $12-18$.

35. Pirt, S. J. (1975). Principles of microbe and cell cultivation. Blackwell Scientific Publications, Oxford: pp. 274.

36. Lee, J. B. and Kim, B. Y. (2002). Growth characteristics of five microalgal species isolated from Jeju Island and four Microalgal stock strains in hatchery. Algae, 17(2): 117 - 125.

37. Rao, C. S., Sathish, T., Brahamaiah, P., Kumar, T. P. and Prakasham, R. S. (2009). Development of a Mathematical Model for Bacillus Circulans Growth and Alkaline Protease Production Kinetics. Journal of Chemical Technology and Biotechnology, 84: $302-307$.

38. Yang, J. S., Rasa, E., Tantayotai, P., Scow, K. M., Yuan, H. L. and Hristova, K. R. (2011). Mathematical model of Chlorella minutissima UTEX2341 growth and lipid production under photoheterotrophic fermentation conditions. Bioresource Technology, 102(3): $3077-3082$.

39. Ho, S., Chen, W. and Chang, J. (2010). Scenedesmus obliquus CNW-Nas a potential candidate for $\mathrm{CO}_{2}$ mitigation and biodiesel production. Bioresource Technology, 101: 8725 - 8730 .

40. Chisti, Y. (2008). Biodiesel from microalgae beats bioethanol. Trends Biotechnology, 26(3): $126-131$.

41. Richmond, A. (2004). Handbook of Microalgae Culture, Biotechnology and Applied Phycology, Blackwell Science Ltd.

42. Folch, J., Lees, M. and Stanley, G. H. S. (1957). A simple method for the isolation and purification of total lipids from animal tissues. Journal of Biological Chemistry, 226: 497 - 509.

43. Frings, C. S. and Dunn, R. T. (1970). A colorimetric method for determination of total serum lipid based on the sulfophospho-vanillin reaction. American Journal of Clinical Pathology, 53: 89- 91

44. Rocha, J. M., Garcia, J. E. and Henriques, M. H. (2003). Growth aspects of the marine microalgae Nannochloropsis gaditana. Biomolecular Engineering, 20:237 - 242.

45. Borowitzka, M. A. (1998). Limits to growth in wastewater treatment with algae. Wong Y. S. and Tam N. F. Y., Editors. Springer Verlag: pp. $203-226$.

46. Goldman, J. C., Azov, Y., Riley, C. B. and Dennett, M. R. (1982). The effect of pH in intensive cultures. i. biomass regulation. Journal of Experimental Marine Biology and Ecology, 57: 1 - 13.

47. Dailey, M. D. and Reish, D. J. (1993). Ecology of the Southern California bight: A synthesis and interpretation. University of California Press. Science: pp. 926.

48. Griffith, M. J. and Harrison, S. T. L. (2009). Lipid productivity as a key characteristic of choosing algal species for biodiesel production. Journal of Applied Phycology, 21: 493 - 507.

49. Tamil Selvam, T. B. (2015). penyingkiran nutrien dari POME dengan menggunakan mikroalga dan sianobakteria yang dipencil dari POME serta potensi biojisim yang diperolehi. Tesis Sarjana, Fakulti Kejuruteraan dan Alam Bina. Universiti Kebangsaan Malaysia. 
50. Vello, V., Phang, S. M., Chu, W. L., Majid, N. A., Lim, P. E. and Loh, S. K. (2013). Lipid productivity and fatty acid composition-selection of Chlorella strains isolated from Malaysia for biodiesel production. Journal of Applied Phycology: 26(3), $1399-1413$.

51. Lembi, C. A. and Waaland, J. R. (1988). Algae and Human Affairs. Cambridge University Press: pp. 590.

52. Gitelson, A., Qiuang, H. and Richmond, A. (1996). Photic volume in photoreactors supporting ultrahigh population densities of the photoautotroph Spirulina Platensis. Applied and Environmental Microbiology, 62: $1570-1573$.

53. Vonshak, A., Abeliovich, A., Boussiba, S. and Richmond, A. (1982). Production of Spirulina biomass: Effect of environmental factors and population density. Biomass, 2: $175-185$.

54. Reichert, C. C., Reinehr, C. O. and Costa, J. A. V. (2006). Semicontinuous cultivation of the cyanobacterium Spirulina platensis in a closed photobioreactor. Brazilian Journal of Chemical Engineering, 23(1): 23 - 28.

55. Minhat, Z., Abd Rahaman, M. S., Takriff, M. S. dan Tan Kofli, N. (2016). Differentiation of biomass composition between isolated and commercial strains of microalgae. Journal of Engineering Science and Technology, 11(5): 737 - 744.

56. Mata, T. M., Martins, A. A. and Caetano, N. S. (2010). Microalgae for biodiesel production and other applications: A review. Renewable and Sustainable Energy Reviews, 14(1): 217 - 232.

57. Khan, S. A., Rashmi, Husain, M. Z., Prasad, S. and Benerjee, U. C. (2009). Prospects of biodiesel production from microalgae in India. Renewable and Sustainable Energy Review, 13: 2361 - 2372.

58. Murphy, D. J. (2005). Plant lipids: Biology, utilisation and manipulation. Oxford, UK: Blackwell Publishing Ltd.

59. Kropat, J., Tottey, S., Birkenhirl, R. P., Depege, N., Huijser, P. and Merchant, S. (2005). Regulator of nutritional copper signalling in Chlamydomonas in an SBP domain protein that recognize the GTAC core of copper response element. Proceedings of the National Academy of Sciences, 102: 18730 - 18735.

60. Sarmidi, A. (2009). Review of biofuel oil and gas production processes from microalgae. Energy Conversion and Management, 50: $1834-1840$. 